\title{
Antibiotics and the Terrestrial Nitrogen Cycle: A Review
}

\author{
Stephanie L. DeVries ${ }^{1,2}$ • Pengfei Zhang ${ }^{1,2,3}$
}

Published online: 26 February 2016

(C) Springer International Publishing AG 2016

\begin{abstract}
The distribution, fate, and effects of human and veterinary antibiotics in the environment have been the subject of intense investigation for nearly two decades. Studies show that the structure and function of microbial communities in soil and sediment are modified by antibiotic exposure but the resulting impact on biogeochemical processes is poorly understood. This review summarizes the most recent data on the present use and physicochemical properties of human and veterinary antibiotics and provides an overview of their occurrence in soil and sediment. This is followed by an examination of the potential effects of antibiotics on microbial nitrogen turnover and methodological approaches to measuring the effects of antibiotics on nitrification and denitrification. Recent studies identified six major classes of antibiotics in soil and sediment, occurring at concentrations between $\mathrm{ng} \cdot \mathrm{kg}^{-1}$ and $\mathrm{mg} \cdot \mathrm{kg}^{-1}$. Among these, tetracycline and fluorquinolone antibiotics are the most resistant to degradation and leaching and may accumulate to high concentrations $\left(\mathrm{mg} \cdot \mathrm{kg}^{-1}\right)$ in terrestrial environments. Less persistent compounds such as the sulfonamides are often detected at lower concentrations (ng $\mathrm{kg}^{-1}$ to $\mu \mathrm{g} \cdot \mathrm{kg}^{-1}$ ) but their occurrence is also reported more frequently.
\end{abstract}

This article is part of the Topical Collection on Land Pollution

Pengfei Zhang

pzhang@ccny.cuny.edu

1 Department of Earth and Atmospheric Sciences, City College of New York, 160 Convent Avenue, New York, NY 10031, USA

2 Department of Earth and Environmental Sciences, Graduate School and University Center, City University of New York, 365 5th Avenue, New York, NY 10016, USA

3 Department of Chemistry, Graduate School and University Center, City University of New York, 365 th Avenue, New York, NY 10016, USA
Only 26 studies were found that investigated the effects of antibiotics on microbial nitrogen cycling. Some antibiotics had no observable effect on nitrogen redox activity in soil and sediment while others appeared to increase or decrease rates of reaction. This lack of consensus could be attributed to a number of different variables including antibiotic dose, method of antibiotic application, variations in the microbial community structure, or method of quantification. We conclude by recommending that future studies adopt a more comprehensive approach to report on changes of the microbial community structure and function as well as the short- and long-term impacts of antibiotics on the accumulation and loss of nitrogen pollutants.

Keywords Antibiotics $\cdot$ Soil $\cdot$ Sediment $\cdot$ Nitrification · Denitrification $\cdot$ Nitrogen pollutants

\section{Introduction}

Since their introduction in the early twentieth century, antibiotics have been proved enormously beneficial to human and animal health. Now used for variety of therapeutic, prophylactic, and growth promotion purposes, global antibiotic consumption has increased considerably. Antibiotic production presently exceeds 100,000 to 200,000 tons per year [1], and a growing proportion of these antibiotics are being administered to poultry and livestock raised in concentrated production facilities [2-5]. As antibiotic usage rises, so too does the risk of antibiotic contamination to the environment. As much as $90 \%$ of the antibiotics being administered are excreted without being metabolized [6] and are poorly removed by wastewater treatment [7]. Consequently, active antibiotic compounds in wastewater, sewage sludge, and manure are 
conveyed to terrestrial and aquatic ecosystems by a combination of disposal, discharge, and use as fertilizer amendments.

A large number of antibiotics have been detected in soil and sediment at concentrations ranging from ng $\mathrm{kg}^{-1}$ to $\mathrm{mg}$. $\mathrm{kg}^{-1}$ [5]. In general, these concentrations are considered therapeutic and are well below the minimum inhibitory concentrations (MICs) established by acute toxicity tests. Sub-lethal or therapeutic doses, however, can promote the development of antibiotic resistance in both target and non-target organisms [8] and have been found to affect the structure and function of ecologically important microbial communities [9].

Microbial communities in soil and sediment play a fundamental role in nutrient recycling and in mitigating global imbalances caused by human activity. This is particularly evident in the $\mathrm{N}$ cycle where inorganic fertilizer use, fossil fuel combustion, and $\mathrm{N}$-fixation cultivation have generated a significant imbalance, depositing up to $140 \mathrm{Tg} \cdot \mathrm{yr}^{-1}$ of reactive $\mathrm{N}$ species to terrestrial and aquatic environments [10]. The increase in reactive $\mathrm{N}$ species has contributed to a number of environmental and human health concerns [11-15]. Mitigation strategies include isolating organisms capable of converting reactive $\mathrm{N}$ to $\mathrm{N}_{2}$ as well as maximizing natural recycling potential in affected watersheds. For example, wastewater treatment commonly includes nitrification and denitrification tanks to reduce the concentration of organic and inorganic $\mathrm{N}$ waste prior to being discharged into surface waters. The latter step of the reduction process, denitrification, reduces the eco-toxic compound nitrate $\left(\mathrm{NO}_{3}{ }^{-}\right)$to $\mathrm{N}_{2}$ or nitrous oxide $\left(\mathrm{N}_{2} \mathrm{O}\right.$ gas $)$ which are lost to the atmosphere. In agroecosystems, denitrification is a naturally occurring ecosystem service and is estimated to remove up to $22 \%$ of applied N [16] and up to $51 \%$ at the watershed scale [17]. Though microbial $\mathrm{N}$ processing is often regarded as a sink for ammonium $\left(\mathrm{NH}_{4}{ }^{+}\right)$and $\mathrm{NO}_{3}{ }^{-}$, it may also serve as a source of eco-toxic nitric oxide (NO) or $\mathrm{N}_{2} \mathrm{O} . \mathrm{N}_{2}$ gas is the most common product of denitrification and is not associated with human health problems or environmental degradation, but up to $3.9 \%$ of denitrification results in the production of $\mathrm{N}_{2} \mathrm{O}$ [18], a powerful greenhouse gas [19] and the leading contributor to stratospheric ozone depletion [20]. NO is a component of smog and is a contributor to a number of human health concerns [21]. Although NO is considered a minor product of nitrification and denitrification, up to $0.75 \%$ of applied $\mathrm{NH}_{4}{ }^{+}-\mathrm{N}$ fertilizers may be lost as $\mathrm{NO}$ [22]. Considerable advances have been made in nutrient management practices to promote high $\mathrm{N}$ use efficiency and to minimize non-point source $\mathrm{NO}_{3}{ }^{-}$and $\mathrm{N}_{2} \mathrm{O}$ pollution. As antibiotics are introduced to soils, however, the resulting impact on microbial activity and $\mathrm{N}$ speciation may reduce the efficacy of these efforts.

Evidence that antibiotics affect the structure of microbial communities in soil, sediment, and sewage sludge is abundant. In a 2010 review, Ding et al. [9] identified 31 studies reporting the effects of 14 antibiotics on microbial communities in soil, sediment, and activated sludge. Reported changes include positive shifts in the ratios of fungi to bacteria and ammonia-oxidizing bacteria (AOB) to ammonia-oxidizing archaea (AOA), increased antibiotic resistance, decreased rates of bacterial growth, and temporal shifts in microbial diversity. Despite functional redundancies within the microbial community, structural changes resulting from exposure to antibiotics may also affect community function (e.g., rates of mineralization, nitrification, and denitrification) and therefore impact important ecosystem services in contaminated soil and sediment. Roose-Amsalag and Laverman [23] provide an excellent overview of the mechanisms that may contribute to these structural and functional changes. In this review, we focus on the effects of antibiotics on the biogeochemical $\mathrm{N}$ cycle in soil and sediment. We first briefly describe the occurrence and fate of antibiotics in the environment, concentrating on studies published since the last major review in 2009 [24]. In the second part of this paper, we discuss the effects of antibiotics on the microbial $\mathrm{N}$ cycle in soil, sediment, and wastewater sludge. In the final section, we discuss methodological approaches to investigating the effects of antibiotics on the microbial $\mathrm{N}$ cycle.

\section{Occurrence of Antibiotics in Soil and Sediment}

The occurrence of antibiotics in the terrestrial environment is well-documented. A number of substantial reviews published between 1999 and 2009 summarize research that reports upon the occurrence of antibiotic and antimicrobial compounds in soil and sediment $[5,6,24,25]$. In addition to their application in human medicine, antibiotics are broadly dispensed for therapeutic, prophylactic, and growth promotion purposes in the livestock and poultry industries. Up to $90 \%$ is excreted without being metabolized $[4,6]$, and recent studies have identified as many as 20 different antibiotic compounds in feces samples from swine, poultry, and livestock production facilities [26-29]. Hospital effluent and wastewater samples are also consistently found to contain a broad range of antibiotic compounds at low concentrations [30,31]. When contaminated manure, sewage sludge, or polluted water are applied to agricultural soils, these residual antibiotic compounds and their degradation products are introduced to the terrestrial environment where they often persist and remain bioavailable [24]. Application of manure to agro-ecosystems is a common practice, particularly in regions where concentrated animal production occurs. In 2009, for example, over 15 million acres of US cropland were fertilized with manure, often in close proximity to livestock and poultry facilities [32]. This figure is likely to grow alongside organic crop production, which doubled between 1997 and 2005 [33]. Although empirical data are scarce, the proportion of cropland receiving manure fertilizers is presumed to be much larger in developing 
countries where use of $\mathrm{N}$ fertilizers is rising dramatically [34]. While the occurrence of antibiotics in soil and sediment has been documented throughout the world [5, 24], the most recent studies have focused extensively on these regions where agricultural output and fertilizer use is on the rise.

\section{Antibiotics in Soil}

A search of scientific databases yielded 20 studies reporting on the occurrence of antibiotics in soil since 2009. Among these, 15 were conducted on field sites in East Asia where animal manure, wastewater, or contaminated surface water were applied to the soil. A total of 36 different antibiotic compounds from six different antibiotic classes were quantified. The median and maximum concentrations reported for each antibiotic are shown in Table 1 alongside the average frequency of detection, region of study, and potential antimicrobial source. The most frequently investigated compounds $(\geq 50 \%$ of studies) include oxytetracycline (OXY), tetracycline (TET), chlortetracycline (CTC), ciprofloxacin (CIP), norfloxacin (NOR), and enrofloxacin (ENR). Sulfonamides were investigated in fewer studies but these and tetracycline antimicrobials were the most frequently detected (up to $100 \%$ ). Notably, no recent studies have investigated the occurrence of the medically important $\beta$-lactams group. Among the antibiotics tested, seven were detected at least once at concentrations in excess of $1 \mathrm{mg} \cdot \mathrm{kg}^{-1}$ : CTC (12.9 $\left.\mathrm{mg} \cdot \mathrm{kg}^{-1}\right)$, OTC $\left(1.41 \mathrm{mg} \cdot \mathrm{kg}^{-1}\right)$, TET $\left(1.01 \mathrm{mg} \cdot \mathrm{kg}^{-1}\right)$, flumequine (FLE, $1.33 \mathrm{mg} \cdot \mathrm{kg}^{-1}$ ), CIP $\left(5.6 \mathrm{mg} \cdot \mathrm{kg}^{-1}\right)$, ENR $\left(1.35 \mathrm{mg} \cdot \mathrm{kg}^{-1}\right)$, and NOR $(2.16 \mathrm{mg}$. $\mathrm{kg}^{-1}$ ). Maximum concentrations for the remaining antibiotics ranged from $0.007 \mu \mathrm{g} \cdot \mathrm{kg}^{-1}$ (anhydrotetracycline, ATC) to $898 \mu \mathrm{g} \cdot \mathrm{kg}^{-1}$ (ofloxacin, OFL), though the median concentration for most of the antibiotics tested rarely exceeded $100 \mu \mathrm{g}$. $\mathrm{kg}^{-1}$. Minimum concentrations were reported for 20 of the 36 antibiotics investigated (not shown), and all but CTC were $<5 \mu \mathrm{g} \cdot \mathrm{kg}^{-1}$ and some as low as $20 \mathrm{ng} \cdot \mathrm{kg}^{-1}$. Several of these studies also reported detection of antibiotics below the limits of quantification (LOQ), indicating that our knowledge about the extent to which antibiotics persist at trace levels in soils is limited by analytical capabilities.

\section{Antibiotics in Sediment}

The occurrence of antibiotics in sediment is reported in 11 recent studies (Table 2). The majority of these sampled sediments in high-intensity agricultural regions such as the Pearl and Yangtze River basins in southern China where wastewater discharge and agricultural runoff are significant sources of antibiotic contamination. Among the 35 antibiotics that were investigated, five were not detected in any sediment sample, and the concentrations of five additional antibiotics were below quantification limits. Tetracycline, sulfonamide, and select fluoroquinolone antibiotics were the most frequently researched compounds, appearing in as many as nine individual studies. Three antibiotics whose concentrations exceed $1 \mathrm{mg} \cdot \mathrm{kg}^{-1}$ in soil were also detected at concentrations exceeding $1 \mathrm{mg} \cdot \mathrm{kg}^{-1}$ in sediment. These include CTC $\left(1.01 \mathrm{mg} \cdot \mathrm{L}^{-1}\right)$, NOR $\left(1.14 \mathrm{mg} \cdot \mathrm{L}^{-1}\right)$, and OFL $\left(1.56 \mathrm{mg} \cdot \mathrm{L}^{-1}\right)$. Overall, the median concentration of antibiotics in sediments $(0.2$ $\left.54.6 \mu \mathrm{g} \cdot \mathrm{kg}^{-1}\right)$ is lower than those in soil $\left(0.23-157 \mu \mathrm{g} \cdot \mathrm{kg}^{-1}\right)$.

\section{Fate of Antibiotics in Soil and Sediment}

Once they have entered the terrestrial environment, the fate of antibiotics is largely governed by their physicochemical properties (Table 3) and interactions with the environmental matrix. In terrestrial environments, antibiotics with high octanolwater partitioning coefficients $\left(\mathrm{K}_{\mathrm{ow}}\right)$ values and large sorption coefficients $\left(\mathrm{K}_{\mathrm{d}}\right)$ tend to sorb strongly to the soil matrix and hence are poorly mobile. The tetracycline class of antibiotics exemplifies this behavior. Their sorption coefficients range

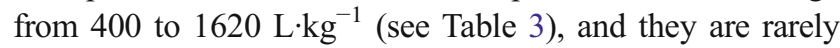
found to migrate beyond upper $10 \mathrm{~cm}$ of the soil column [84]. Poor mobility and long half-lives provide opportunity for fluoroquinolones (120-2310 days) and tetracyclines (4001620 days) to accumulate over time, likely accounting for the frequency at which these antibiotics are detected in soils at concentrations in excess of $500 \mu \mathrm{g} \cdot \mathrm{kg}^{-1}$, especially where manure applications are frequent. Since both sorb strongly to soil and sediment particles, comparably high concentrations of fluoroquinolones and tetracyclines are also observed in sediment. Sulfonamides are among the most frequently detected antibiotic compounds in both soil and sediment but their low $\mathrm{K}_{\mathrm{d}}$ values (0.6-4.9) render these compounds highly mobile. In combination with low half-lives ( $\max t_{1 / 2}=21.3$ days), sulfonamides do not show the same tendency to accumulate and are infrequently detected at concentrations beyond $50 \mu \mathrm{g} \cdot \mathrm{kg}^{-1}$ in soil or $5 \mu \mathrm{g} \cdot \mathrm{kg}^{-1}$ in sediment.

\section{Effects of Antibiotics on the Terrestrial Nitrogen Cycle}

\section{The Nitrogen Cycle}

The $\mathrm{N}$ cycle is a global biogeochemical cycle in which $\mathrm{N}$ flows between atmospheric, aqueous, and terrestrial reservoirs. Microbial activity in soil and sediment drives a significant portion of the bulk cycle, converting organic $\mathrm{N}$ into plant available forms $\left(\mathrm{NH}_{4}{ }^{+}\right.$and $\left.\mathrm{NO}_{3}{ }^{-}\right)$and reducing excess inorganic $\mathrm{N}$ to gasses $\left(\mathrm{N}_{2}\right.$ and $\left.\mathrm{N}_{2} \mathrm{O}\right)$ that escape to the atmosphere, completing the cycle (Fig. 1). $\mathrm{NH}_{4}{ }^{+}$accumulates in soil as a result of mineralization, $\mathrm{N}$ fixation (legumes), direct deposition from the atmosphere, or by application of inorganic fertilizers containing $\mathrm{NH}_{4}{ }^{+}$salts, e.g., $\left(\mathrm{NH}_{4}\right)_{2} \mathrm{SO}_{4} \cdot \mathrm{NH}_{4}{ }^{+}$strongly sorbs to the negatively charged surfaces of soil minerals and 


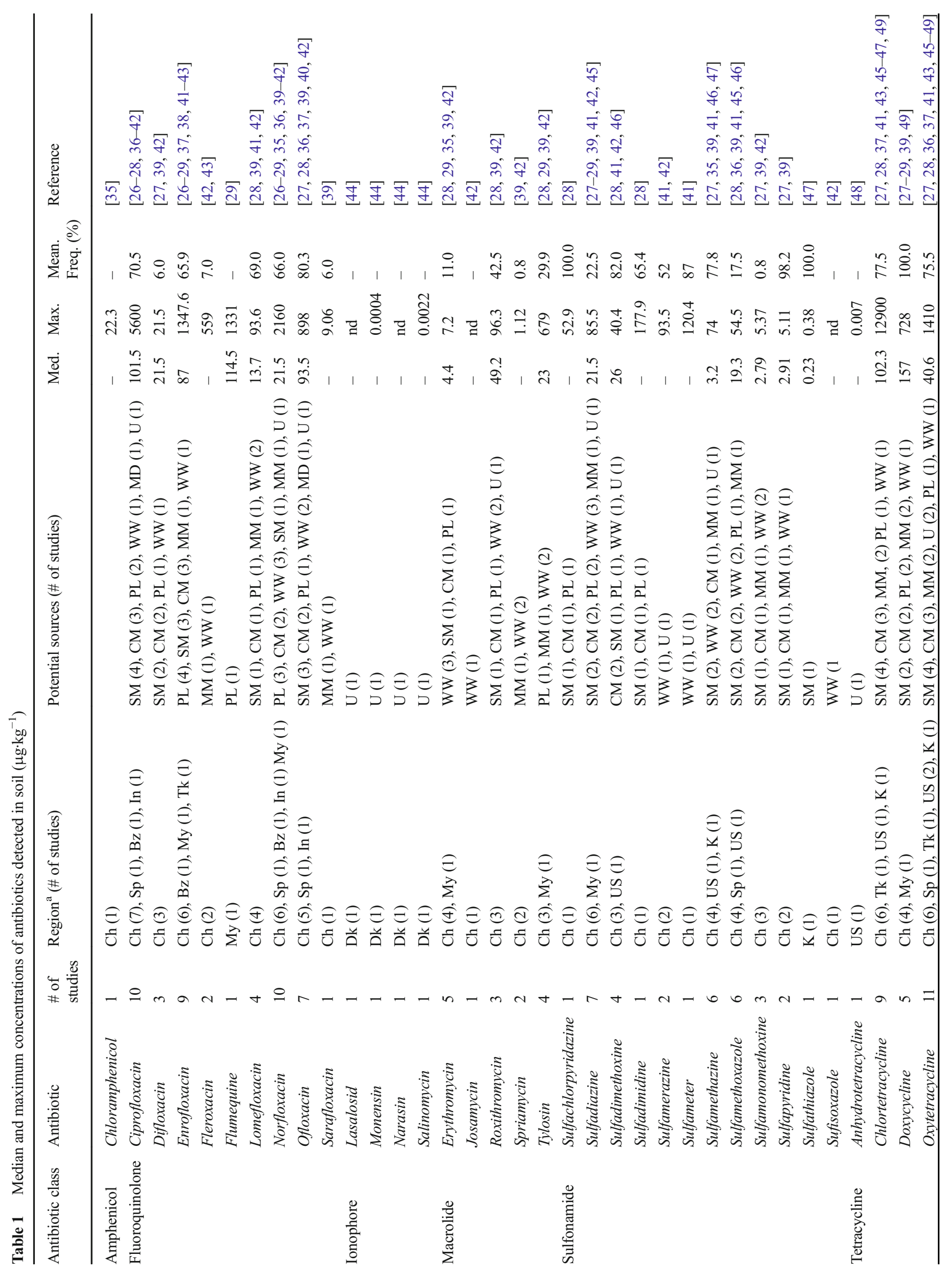


soil organic matter (SOM) and is therefore resistant to leaching, but it may be lost by surface runoff, plant uptake, biological nitrification, or annomox reactions. $\mathrm{NO}_{3}^{-}$that is produced via nitrification or directly added to soils via inorganic fertilizers, e.g., $\mathrm{KNO}_{3}$, is susceptible to a number of losses. These include plant uptake, assimilation into microbial tissue, leaching, and biological denitrification. In the following sections, we will briefly review the biology of nitrification and denitrification, followed by an examination of the effects antibiotics and antimicrobials have on these processes.

\section{Nitrification}

Nitrification is a general term used to describe naturally occurring $\mathrm{NH}_{4}{ }^{+}$oxidation reactions. The most common oxidation pathway leads to the production of $\mathrm{NO}_{3}{ }^{-}$via the intermediate product, $\mathrm{NO}_{2}{ }^{-}$. Studies of chemoautotrophic nitrifying organisms such as Nitrosomonas europaea describe the $\mathrm{NH}_{4}{ }^{+} \rightarrow \mathrm{NO}_{2}{ }^{-}$oxidation as a two-step enzymatic process (see Eqs. 1 and 2) catalyzed by ammoniamonoxygenase (AMO) and hydroxylamine oxidoreductase (HAO), respectively [85]:

$\mathrm{NH}_{4}^{+}+\mathrm{O}_{2}+\mathrm{H}^{+} \stackrel{\mathrm{AMO}}{\rightarrow} \mathrm{NH}_{2} \mathrm{OH}+\mathrm{H}_{2} \mathrm{O}$

$\mathrm{NH}_{2} \mathrm{OH}+\mathrm{H}_{2} \mathrm{O} \stackrel{\mathrm{HAO}}{\rightarrow} \mathrm{NO}_{2}^{-}+5 \mathrm{H}^{+}$

The resulting intermediate product, $\mathrm{NO}_{2}{ }^{-}$, is rapidly oxidized to $\mathrm{NO}_{3}{ }^{-}$. Chemoautotrophic nitrifiers of the genus Nitrobacter and Nitrosomonas express the nitrite oxidoreductase (NOR) enzyme, which facilitates a second oxidation reaction $\left(\mathrm{NO}_{2}{ }^{-} \rightarrow \mathrm{NO}_{3}{ }^{-}\right.$) to provide energy for cell growth [86, 87]. Although considered secondary to autotrophic AOA and AOB in most soils, a number of heterotrophic nitrifiers have also been isolated. These include the gram-negative bacteria Alcaligenes faecalis and Pseudomonas aeruginosa [88, 89]. The mechanisms for heterotrophic nitrification are poorly understood, and the process yields insufficient energy to support heterotrophic cell growth [86]. Heterotrophic nitrification has been also reported to include alternate redox pathways following the initial $\mathrm{NH}_{4}{ }^{+} \rightarrow \mathrm{NH}_{2} \mathrm{OH}$ oxidation step. These include oxidation of $\mathrm{NH}_{2} \mathrm{OH}$ to $\mathrm{NO}$ or $\mathrm{N}_{2} \mathrm{O}$ (nitrifier nitrification) and reduction of $\mathrm{NO}_{2}^{-}$to $\mathrm{N}_{2} \mathrm{O}$ (nitrifier denitrification) [89, 90].

\section{Effects of Antibiotics on Nitrification}

A literature search identified a total of 13 studies that investigated the effects of 19 different antibiotics, antimicrobials, and antibiotic mixtures on nitrification in soil, wastewater sludge, or pure culture (Table 4). Inhibition is often deemed the most probable effect of antibiotics on nitrification, but this hypothesis is ineffectually supported by the present studies. Among 19 antibiotics and antimicrobials investigated, fewer than half 
Table 2 Minimum and maximum concentrations of antibiotics detected in sediment $\left(\mu \mathrm{g} \cdot \mathrm{kg}^{-1}\right)$

\begin{tabular}{|c|c|c|c|c|c|c|}
\hline Antibiotic class & Antibiotic & \# Studies & Region ${ }^{\text {a }}$ (\# of studies) & Med. & Max. & Reference \\
\hline \multirow[t]{3}{*}{ Amphenicol } & Chloramphenicol & 1 & $\mathrm{Ch}(1)$ & - & $<$ LOQ & {$[50]$} \\
\hline & Florfenicol & 1 & Ch (1) & - & $<$ LOQ & {$[50]$} \\
\hline & Thiamphenicol & 1 & $\mathrm{Ch}(1)$ & - & $<$ LOQ & {$[50]$} \\
\hline \multirow[t]{8}{*}{ Fluoroquinolone } & Ciprofloxacin & 1 & $\mathrm{Ch}(1)$ & 16.6 & 197 & {$[50,51]$} \\
\hline & Difloxacin & 1 & $\mathrm{Ch}(1)$ & - & nd & [51] \\
\hline & Enrofloxacin & 4 & Ch (3), US (1) & 4.84 & 137 & {$[27,50-52]$} \\
\hline & Fleroxacin) & 1 & Ch (1) & 6.69 & 6.69 & [51] \\
\hline & Lomefloxacin & 3 & Ch (3) & 2.78 & 29 & {$[27,51,53]$} \\
\hline & Norfloxacin & 6 & $\mathrm{Ch}(6)$ & 26.6 & 1140 & {$[27,50,51,53-55]$} \\
\hline & Ofloxacin & 8 & $\mathrm{Ch}(7), \mathrm{Sp}(1)$ & 54.6 & 1560 & {$[27,36,50,51,53-55]$} \\
\hline & Sarafloxacin & 1 & $\mathrm{Ch}(1)$ & - & nd & {$[51]$} \\
\hline \multirow[t]{4}{*}{ Ionophore } & Lasalosid & 1 & $\mathrm{Dk}(1)$ & - & nd & {$[44]$} \\
\hline & Monensin & 1 & Dk (1) & - & nd & {$[44]$} \\
\hline & Salinomycin & 1 & $\mathrm{Dk}(1)$ & - & 7E-04 & {$[44]$} \\
\hline & Narasin & 1 & Dk (1) & - & 4E-04 & {$[44]$} \\
\hline \multirow[t]{4}{*}{ Macrolide } & Erythromycin & 5 & $\mathrm{Ch}(5)$ & 14.8 & 385 & {$[27,51,53-55]$} \\
\hline & Roxithromycin & 5 & $\mathrm{Ch}(5)$ & 3.42 & 302 & {$[50,51,53-55]$} \\
\hline & Spriamycin & 1 & $\mathrm{Ch}(1)$ & 61.9 & 61.9 & {$[55]$} \\
\hline & Tylosin & 1 & $\mathrm{Ch}(1)$ & - & nd & {$[27]$} \\
\hline \multirow[t]{12}{*}{ Sulfonamide } & Sulfachlorpyridazine & 1 & US (1) & - & nd & [52] \\
\hline & Sulfadiazine & 6 & $\mathrm{Ch}(6)$ & 1.27 & 83.9 & {$[27,50,51,53-55]$} \\
\hline & Sulfadimethoxine & 3 & US (2), Ch (1) & 0.2 & 0.2 & {$[46,51,52]$} \\
\hline & Sulfamerazine & 3 & Ch (2), US (1) & 1.44 & 2.47 & {$[50-52]$} \\
\hline & Sulfamethazine & 9 & Ch (6), US (2), K (1) & 2.87 & 248 & {$[27,46,47,50-55]$} \\
\hline & Sulfamethizole & 1 & USA (1) & - & nd & [52] \\
\hline & Sulfamethoxazole & 9 & Ch (5), US (2), K (1), Sp (1) & 0.52 & 7.86 & {$[27,36,46,47,50-54]$} \\
\hline & Sulfamonomethoxine & 2 & $\mathrm{Ch}(2)$ & 1.55 & 1.86 & {$[27,51]$} \\
\hline & Sulfapyridine & 2 & $\mathrm{Ch}(2)$ & 3.71 & 9.12 & {$[50,51]$} \\
\hline & Sulfaquinoxaline & 1 & Ch (1) & 0.54 & 0.959 & [50] \\
\hline & Sulfathiazole & 5 & Ch (4), US (1) & 2.06 & 5.94 & {$[47,50-52,55]$} \\
\hline & Sulfisoxazole & 1 & $\mathrm{Ch}(1)$ & 1.71 & 1.71 & {$[51]$} \\
\hline \multirow[t]{4}{*}{ Tetracycline } & Chlorotetracycline & 6 & Ch (4), US (2) & 10.5 & 1010 & {$[27,46,47,50,52,53]$} \\
\hline & Doxycycline & 3 & $\mathrm{Ch}(3)$ & 14.6 & 444 & {$[27,50,53]$} \\
\hline & Oxytetracycline & 9 & Ch (5), US (2), K (1), Sp (1) & 41.5 & 214 & {$[27,36,46,47,50,52-55]$} \\
\hline & Tetracylcine & 9 & Ch (5), US (2), K (1), Sp (1) & 42 & 94.79 & {$[27,36,46,47,50,52-55]$} \\
\hline
\end{tabular}

Antibiotics whose concentration were below the limits of quantification (LOQ) are indicated as $<$ LOQ

$n d$ none detected

${ }^{\text {a }}$ China (Ch), Malaysia (My), Korea (K), Spain (Sp), United States (US), Denmark (Dk)

(9) show that the antibiotic or antimicrobial tested inhibited nitrification and the minimum inhibitory concentration (MIC) ranged from $200 \mu \mathrm{g} \mathrm{kg}^{-1}$ (sulfadimethoxine, SDM) [95] to $200 \mathrm{mg} \mathrm{kg}^{-1}$ (TET) [103]. Based on their low sorption coefficients (Table 3), sulfonamide antibiotics are likely to be the most bioavailable, which may account for the low inhibitory concentration of SDM relative to more sorptive species like CTC and TET. Although this claim is poorly supported by the MIC of other sulfonamides, a fair comparison is difficult because the lowest tested concentrations of the other sulfonamides were $2 \mathrm{mg} \mathrm{kg}^{-1}$ (sulfadiazine, SDZ) and $4 \mathrm{mg} \mathrm{kg}^{-1}$ (sulfamethoxazole, SMX).

Among the remaining antibiotics, the following five had no observable effect on nitrification: CTC, difloxacin (DIF), monensin (MON), ivermectin (INV), and chloramphenicol $(\mathrm{CPH})$. That nitrification rates were not significantly modified at either low $\left(\mu \mathrm{g} \cdot \mathrm{kg}^{-1}\right)$ or high $\left(\mathrm{mg} \cdot \mathrm{kg}^{-1}\right)$ therapeutic concentrations for some antibiotics do not conclusively show that the 
Table 3 Usage and physicochemical properties of select antibiotics

\begin{tabular}{|c|c|c|c|c|c|c|}
\hline Antibiotic class & Antibiotic & Usage & $\mathrm{pKa}$ & $\log \mathrm{K}_{\mathrm{ow}}$ & $\mathrm{K}_{\mathrm{d}}\left(\mathrm{L} \cdot \mathrm{kg}^{-1}\right)$ & $\begin{array}{l}\text { Half-life in } \\
\text { soil (days) }\end{array}$ \\
\hline \multirow[t]{4}{*}{ Fluoroquinolone } & Ciprofloxacin & Human Health, Veterinary [56] & $6.09^{\mathrm{a}}, 6.82^{\mathrm{b}}[57]$ & 0.28 & $61,000[58]$ & $2310 \pm 1155[59]$ \\
\hline & Enrofloxacin & Veterinary $[56]$ & $6.27^{\mathrm{a}}, 8.3^{\mathrm{b}}[58]$ & $1.1[58]$ & $260-6000[58]$ & $\mathrm{n} / \mathrm{a}$ \\
\hline & Norfloxacin & Human Health [56] & $6.40^{\mathrm{a}}, 8.68^{\mathrm{b}}[60]$ & $-1.0[61]$ & $\mathrm{n} / \mathrm{a}$ & $1155[59]$ \\
\hline & Ofloxacin & Human Health [56] & $5.97^{\mathrm{a}}, 8.28^{\mathrm{b}}[58]$ & $0.35[58]$ & $310[58]$ & $1386 \pm 434[59]$ \\
\hline \multirow[t]{3}{*}{ Macrolide } & Erythromycin & Human Health ${ }^{\mathrm{i}}$, Veterinary [56] & $8.88^{\mathrm{a}}, 12.44^{\mathrm{b}}[62]$ & $3.06[62]$ & $\mathrm{n} / \mathrm{a}$ & $360[63]$ \\
\hline & Roxithromycin & Human Health ${ }^{i}[56]$ & $8.80^{\mathrm{a}}, 12.45^{\mathrm{b}}[64]$ & $2.75[65]$ & $\mathrm{n} / \mathrm{a}$ & $>>120[66]$ \\
\hline & Tylosin & Veterinary $[56]$ & $7.50^{\mathrm{c}}[67]$ & $3.5[58]$ & 129.5 (est.) [68] & $8.3[66]$ \\
\hline \multirow[t]{6}{*}{ Sulfonamide } & Sulfachlorpyridazine & Veterinary $[56]$ & $1.87^{\mathrm{d}}, 5.45^{\mathrm{e}}[67]$ & $0.31[69]$ & $09-1.8[70]$ & $21.3[71]$ \\
\hline & Sulfadiazine & Human Health ${ }^{\mathrm{k}}$, Veterinary [56] & $2.01^{\mathrm{d}}, 6.15^{\mathrm{e}}[72]$ & $-0.092[72]$ & $2.0[73]$ & $12-18[74]$ \\
\hline & Sulfamethazine & Veterinary $[75]$ & $2.65^{\mathrm{d}}, 7.65^{\mathrm{e}}[58]$ & $0.89[58]$ & $0.6-3.1[58]$ & $18.6[71]$ \\
\hline & Sulfamethoxazole & Human Health ${ }^{\mathrm{k}}[56]$ & $1.97^{\mathrm{d}}, 5.70^{\mathrm{e}}[76]$ & $0.89[76]$ & $\mathrm{n} / \mathrm{a}$ & $9-18.3[77]$ \\
\hline & Sulfamonomethoxine & Veterinary [56] & $1.98^{\mathrm{d}}, 5.96^{\mathrm{e}}[78]$ & $0.70[69]$ & $\mathrm{n} / \mathrm{a}$ & $\mathrm{n} / \mathrm{a}$ \\
\hline & Sulfathiazole & Veterinary $[79]$ & $2.01^{\mathrm{d}}, 7.11^{\mathrm{e}}[67]$ & $0.05[69]$ & $4.9[58]$ & $\mathrm{n} / \mathrm{a}$ \\
\hline \multirow[t]{4}{*}{ Tetracycline } & Chlortetracycline & Human Health ${ }^{\mathrm{k}}$, Veterinary [56] & $3.3^{\mathrm{f}}, 7.44^{\mathrm{g}}, 9.27^{\mathrm{h}}[80]$ & $-0.36[80]$ & $794[81]$ & $25.9-30.8[82]$ \\
\hline & Doxycycline & Human Health ${ }^{\mathrm{k}}$, Veterinary [56] & $3.02^{\mathrm{f}}, 7.97^{\mathrm{g}}, 9.15^{\mathrm{h}}[67]$ & $0.02[69]$ & $\mathrm{n} / \mathrm{a}$ & $533 \pm 23[59]$ \\
\hline & Oxytetracycline & Human Health ${ }^{\mathrm{k}}$, Veterinary [56] & $3.3^{\mathrm{f}}, 7.3^{\mathrm{g}}, 9.1^{\mathrm{h}}[83]$ & $1.22[83]$ & $680-1030$ [84] & $30.2-41.3[82]$ \\
\hline & Tetracycline & Human Health ${ }^{\mathrm{k}}$, Veterinary [56] & $3.32^{\mathrm{f}}, 7.78^{\mathrm{g}}, 9.58^{\mathrm{h}}[67]$ & $1.30[69]$ & $400-1620[58]$ & $578[59]$ \\
\hline
\end{tabular}

$n / a$ data not available

${ }^{\text {a }}$ Carboxyl group

${ }^{\mathrm{b}}$ Protonated amino group

${ }^{\mathrm{c}}$ Basic dimethylamine group

${ }^{\mathrm{d}}$ Basic amine group

${ }^{\mathrm{e}}$ Acidic amide group

${ }^{\mathrm{f}}$ Tri-carbonyl group

${ }^{\mathrm{g}}$ Dimethylamine group

${ }^{\mathrm{h}} \beta$-diketone

${ }^{\mathrm{i}}$ Critically important antibiotic

${ }^{\mathrm{k}}$ Highly important antibiotic

nitrifying community was unaffected. For example, Luis Campos et al. [91] observed no change in net nitrification in soils treated with either $10-250 \mathrm{mg} \cdot \mathrm{L}^{-1} \mathrm{CPH}$ or lower doses $\left(<100 \mathrm{mg} \cdot \mathrm{L}^{-1}\right)$ of OTC but suggested that shifts in the ratio of ammonia-oxidizing bacteria (AOB) to ammonia-oxidizing archaea (AOA) may account for the lack of apparent response. Kotzerke et al. [99] proposed a similar explanation, stating that the contributions of fungal and archaeal nitrification may be sufficient to regulate net nitrification when AOB are inhibited. Although one study concludes that AOB are more important in N-rich soils [104], others tend to support the hypothesis that AOA are able to regulate nitrification when $\mathrm{AOB}$ are compromised. It has also been reported that AOA outnumber and likely outperform AOB [105].

In addition to providing resiliency when AOB are compromised, some studies have shown that population growth among AOA [106] or dose-related shifts in the fungi to bacteria ratio [107] is stimulated by some antibiotics. These types of shifts may partially explain stimulated nitrification, an outcome that was observed in soils treated with NOR $\left(1 \mathrm{mg} \cdot \mathrm{kg}^{-1}\right)$ [74], bacitracin (BAC, $100 \mathrm{mg} \cdot \mathrm{kg}^{-1}$ ), and a mixture of BAC, MON, and INV(0.1-100 mg $\left.\mathrm{kg}^{-1}\right)$ [96]. In the latter treatment, a large shift in the AOA:AOB was correlated to accelerated nitrification observed in short-term soil mesocosms 7 and 30 days after receiving a $100-\mathrm{mg} \cdot \mathrm{kg}^{-1}$ dose [96]. In an associated field experiment where lower doses $(0.1-10 \mathrm{mg}$. $\mathrm{kg}^{-1}$ ) were applied, stimulation did not become evident until a year after the initial antibiotic application. AOA:AOB ratios were not shown for the field soils, but the delayed (1 year) response at lower doses suggests that changes in the microbial community may simply proceed more slowly when exposed to lower concentrations.

Stimulation was also observed in soil microcosms treated with CIP [92] and NOR [74]. In these experiments, nitrification was stimulated only at the lowest doses tested $(1 \mathrm{mg}$. $\mathrm{kg}^{-1}$ ). At higher concentrations ( $>5$ and $>100 \mathrm{mg} \cdot \mathrm{kg}^{-1}$, respectively), CIP and NOR inhibited nitrification. The apparent 


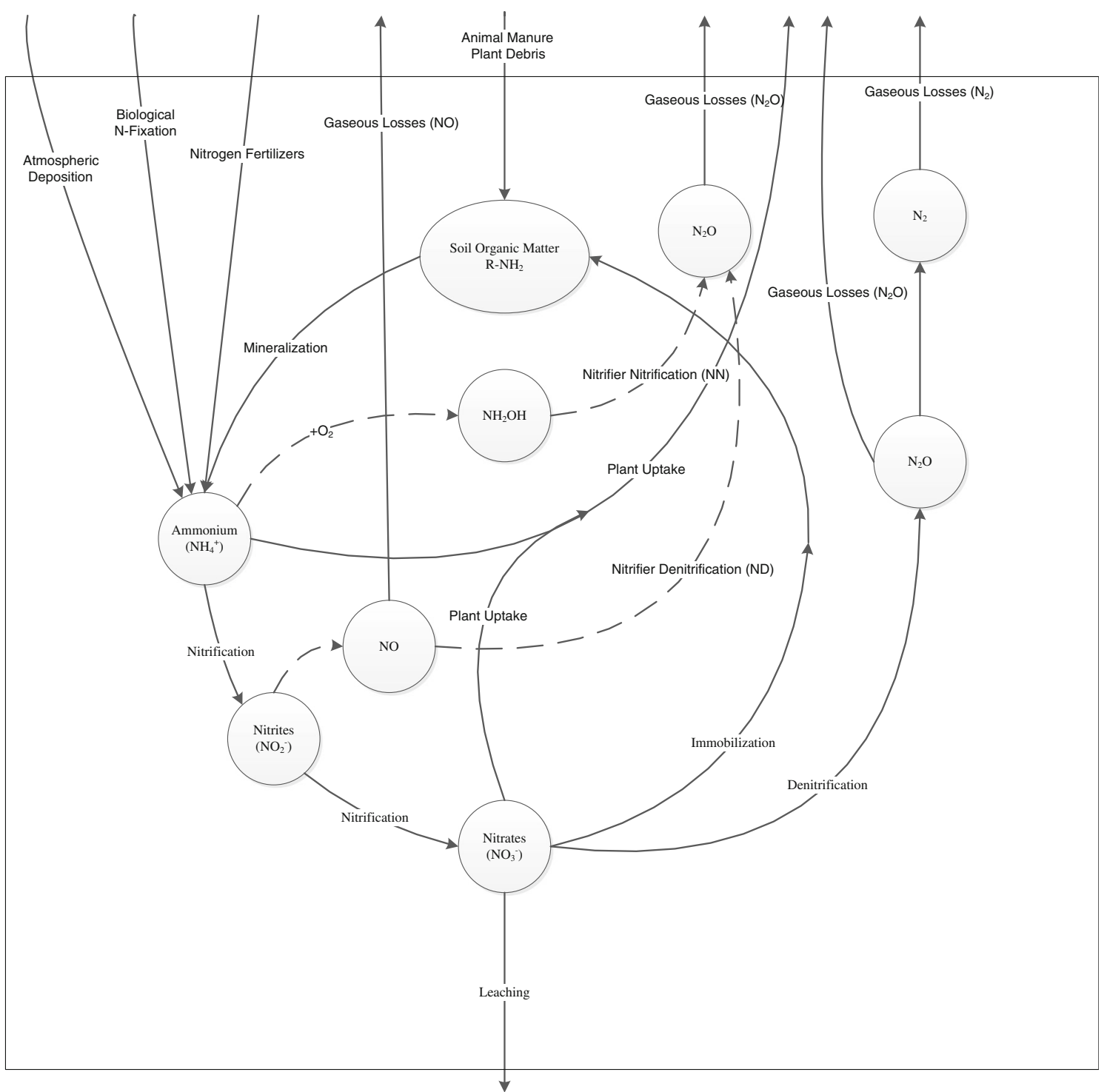

Fig. 1 Biogeochemical nitrogen cycle

disagreement at different doses is characteristic of hormesis, a J-shaped dose response in which low doses of a toxin stimulate response and high doses are inhibitory [108], though hormesis has never been explicitly studied for complex microbial communities such as those occurring in soils.

Presently, changes to microbial communities are the dominant hypotheses proposed to explain why nitrification is unchanged or even stimulated in some soils or sewage sludge following exposure to antibiotics. Positive shifts in the AOA:AOB ratio, for example, illustrate functional redundancy in the soils that may compensate for reduced AOB activity leading to no observed effect. Alternately, if AOA outperform $\mathrm{AOB}$, a shift in the AOA:AOB ratio may accelerate nitrification in some soils following exposure to antibiotics. These changes do provide a potential explanation for stimulated nitrification where antibiotic exposure occurs, but they do not satisfactorily explain how the same dose of a single antibiotic can yield different results when applied to different media. For example, Louvet et al. [97] evaluated the effect of 0.1-20 mg. $\mathrm{L}^{-1}$ erythromycin (ERY) on nitrification in two different activated sludge materials. In the first sludge (Nancy), nitrification was inhibited $\left(>10 \mathrm{mg} \cdot \mathrm{kg}^{-1}\right)$, an observation corroborated by Katipoglu-Yazan et al. [103]. When Louvet et al. applied the same treatment to a different sludge (Epinal), however, a stimulatory effect was observed. Disagreement between these results may point to the role of the endemic microbial community in determining its response to antibiotic exposure. Though the sludges were obtained from the same region, the Nancy sludge was prepared with a biofilm on sand whereas the Epinal sludge was prepared in an oxidation ditch with no settling. These two sludge-forming environments may favor different groups of nitrifying organisms whose responses to ERY are sufficiently unique that stimulation is observed in one and inhibition in the other. 


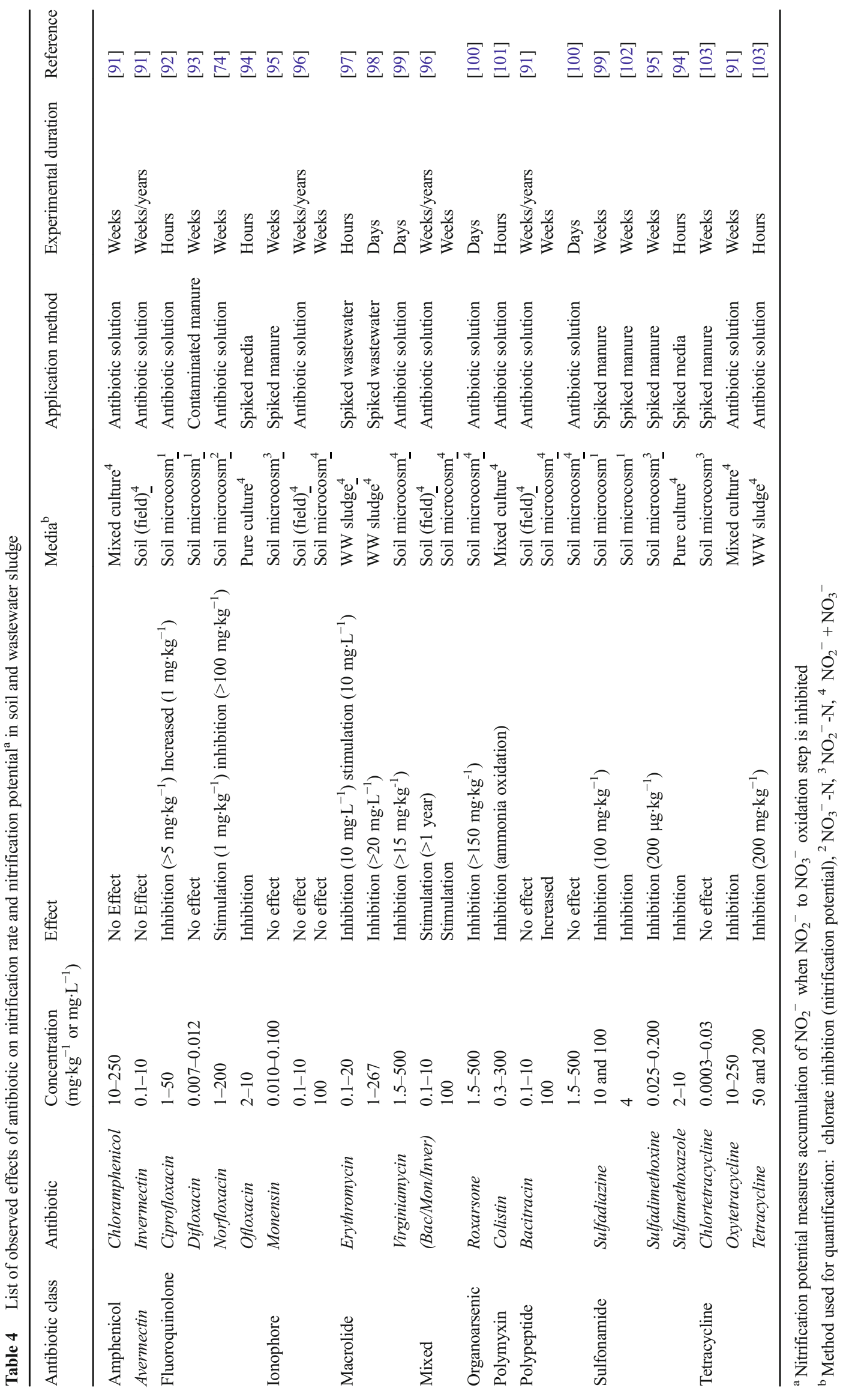




\section{Denitrification}

Denitrification is a naturally occurring process in which $\mathrm{NO}_{3}{ }^{-}$ is sequentially reduced to $\mathrm{N}_{2}$ gas (Eq. 3):

$\mathrm{NO}_{3}^{-} \rightarrow \mathrm{NO}_{2}^{-} \rightarrow \mathrm{NO}(\mathrm{g}) \rightarrow \mathrm{N}_{2} \mathrm{O}(\mathrm{g}) \rightarrow \mathrm{N}_{2}(\mathrm{~g})$

Denitrifying organisms include a diverse group of bacteria, fungi, and archaea [109], but the majority of denitrification is attributed to heterotrophic anaerobes. The best-studied denitrifying bacteria include Paracoccus denitrificans and Pseudomonas stutzeri [110]. Each stage of the denitrification process is facilitated by one or more membrane-bound enzymes including: NAR $\left(\mathrm{NO}_{3}{ }^{-}\right.$reductase $), \mathrm{NIR}\left(\mathrm{NO}_{2}{ }^{-}\right.$reductase), NOR (NO reductase), and NOS $\left(\mathrm{N}_{2} \mathrm{O}\right)$ reductase [111]. Although $\mathrm{N}_{2}$ is the dominant denitrification product ( $>95 \%$ ), some fraction is lost as free $\mathrm{NO}$ or $\mathrm{N}_{2} \mathrm{O}$.

\section{Effects of Antibiotics on Denitrification}

The effects of 18 different antibiotics on denitrification have been investigated, and the results vary considerably among the different solid matrices and concentrations tested (Table 5). Inhibition was reported in soil, sediment, and/or groundwater treated with the following 12 antibiotics: BAC, amoxicillin (AMO), clarithromycin (CLA), CTC, ERY, FLE, gentamicin (GTC), narasin (NAR), SDZ, SMZ, SMX, and vancomycin (VAN). In sediment, Costanzo et al. [113], Yan et al. [115], Laverman et al. [120], and Roose-Amsaleg et al. [119] measured the effects of eight different antibiotics on denitrification rate. Inhibition relative to the control was observed for seven of these antibiotics, but none at a concentration $<1000 \mu \mathrm{g} \cdot \mathrm{L}^{-1}$ except where SMZ $\left(0.05-100 \mu \mathrm{g} \cdot \mathrm{L}^{-1}\right)$ was applied [116]. Because SMZ has very low sorption coefficient in comparison to most of the other antibiotics tested, what appears to be greater sensitivity to this antibiotic may simply be a reflection of bioavailability. On the other hand, SMX is equally mobile and was only observed to inhibit denitrification in sediment at concentrations in excess of $57.5 \mathrm{mg} \cdot \mathrm{L}^{-1}$ [115]. Because the antibiotic agencies and physicochemical properties of SDZ and SMX are comparable, a 1000-fold difference between their reported MICs is unexpected, but there are a number of experimental dissimilarities that may account for it. For example, Yan et al. [115] conducted a series of flow-through reactor experiments in which the input solution containing 0.24, 2.1, 11 , or $57,500 \mu \mathrm{g} \cdot \mathrm{L}^{-1} \mathrm{SMX}$ was continuously supplied over a period of weeks, and steady-state denitrification was measured from the ratio of effluent to influent $\mathrm{NO}_{2}{ }^{-}+\mathrm{NO}_{3}{ }^{-}$. Significant inhibition was observed only at the $57,500-\mu \mathrm{g}$. $\mathrm{L}^{-1}$ dose, leading the authors to suggest that chronic exposure to therapeutic doses may promote SMX resistance. Resistance is less likely to develop in short-term experiments following a single antibiotic dose, which may explain why Hou et al. [116] were able to observe inhibition in sediments $1-8 \mathrm{~h}$ after they were treated with lower doses of SDZ $\left(0.05-100 \mu \mathrm{g} \cdot \mathrm{L}^{-1}\right)$. On the other hand, the effects of SMX were not investigated for any dose between 11 and $52,500 \mu \mathrm{g} \cdot \mathrm{L}^{-1}$, and future studies conducted within this range may identify inhibitory concentrations of SMX that are more consistent with the results of shortterm studies. Furthermore, the resistance hypothesis does not explain why therapeutic concentrations of SMX and SMZ inhibited denitrification in groundwater studies even when the antibiotic was continuously supplied [117, 118]. A total of 7 antibiotics (3 sulfonamide, $1 \beta$-lactam, 1 aminoglycoside, 1 ionophore, and 1 polypeptide) inhibited denitrification in soils, while several others were reported to stimulate denitrification, particularly at ultra-low (ng. $\mathrm{kg}^{-1}$ or ng. $\mathrm{L}^{-1}$ ) concentrations. For example, SMX inhibited denitrification in groundwater at $1.2 \mu \mathrm{g} \cdot \mathrm{L}^{-1}$ [118] but accelerated $\mathrm{NO}_{3}{ }^{-}$ reduction in flow-through column experiments $\left(1 \mathrm{ng} \cdot \mathrm{L}^{-1}\right)$, and the effect was amplified over time [112].

\section{Effects of Antibiotics on $\mathrm{NO}$ and $\mathrm{N}_{2} \mathrm{O}$ Emissions}

Eco-toxic $\mathrm{NO}$ and $\mathrm{N}_{2} \mathrm{O}$ gases are minor products of nitrification and denitrification. $\mathrm{N}_{2} \mathrm{O}$ is produced by bacteria, archaea, and some fungi in soil and sediment as a byproduct of nitrification or as free intermediates of denitrification. Under anoxic conditions, the predominant pathway is via the sequential reduction: $\mathrm{NO}_{3}{ }^{-} \rightarrow \mathrm{NO}_{2}{ }^{-} \rightarrow \mathrm{NO} \rightarrow \mathrm{N}_{2} \mathrm{O}$. Although a portion of $\mathrm{N}_{2} \mathrm{O}$ produced in soil and sediment will be consumed by bacteria able to use it as a terminal electron acceptor [121, 122], some will ultimately be diffused to the surface and lost to the atmosphere. Because $\mathrm{N}_{2} \mathrm{O}$ is a potent greenhouse gas and can reduce stratospheric ozone, the flux of $\mathrm{N}_{2} \mathrm{O}$ from soil and sediment is of significant interest. However, the impact of terrestrial antibiotics on $\mathrm{N}_{2} \mathrm{O}$ emissions from soil and sediment has scarcely been addressed. In fact, only 2 studies were found that explicitly investigate this topic. Both observed a rise $\mathrm{N}_{2} \mathrm{O}$ flux in soils treated with sub-therapeutic doses of antibiotics. Hou et al. [116] tested the effects of SMZ (0.05$\left.100 \mu \mathrm{g} \cdot \mathrm{L}^{-1}\right)$ and reported an increase in $\mathrm{N}_{2} \mathrm{O}$ flux by as much as $300 \%\left(>50 \mu \mathrm{g} \cdot \mathrm{L}^{-1} \mathrm{SMZ}\right)$ within $8 \mathrm{~h}$ of exposure. Because the increase in $\mathrm{N}_{2} \mathrm{O}$ flux coincided with inhibited denitrification, the authors propose that antibiotics may more strongly inhibit $\mathrm{N}_{2} \mathrm{O}$ reduction to $\mathrm{N}_{2}$ than $\mathrm{N}_{2} \mathrm{O}$ production itself, resulting in an increased $\mathrm{N}_{2} \mathrm{O}: \mathrm{N}_{2}$ production ratio [116]. DeVries et al. [112] proposed a similar conclusion upon observing a threefold increase in $\mathrm{N}_{2} \mathrm{O}$ flux in soils amended with 1-1000 $\mathrm{ng} \cdot \mathrm{kg}^{-1} \mathrm{NAR}$ after a 3-day incubation. Alternately, increased denitrification, which was reported for 4 antibiotics in soil and groundwater, may also increase $\mathrm{N}_{2} \mathrm{O}$ flux without an associated shift in the $\mathrm{N}_{2} \mathrm{O}: \mathrm{N}_{2}$ ratio and ought to be investigated in future studies. $\mathrm{NO}$ is also produced in small quantities during nitrification and is a free intermediate of denitrification. Though it is a major component of smog, no studies 


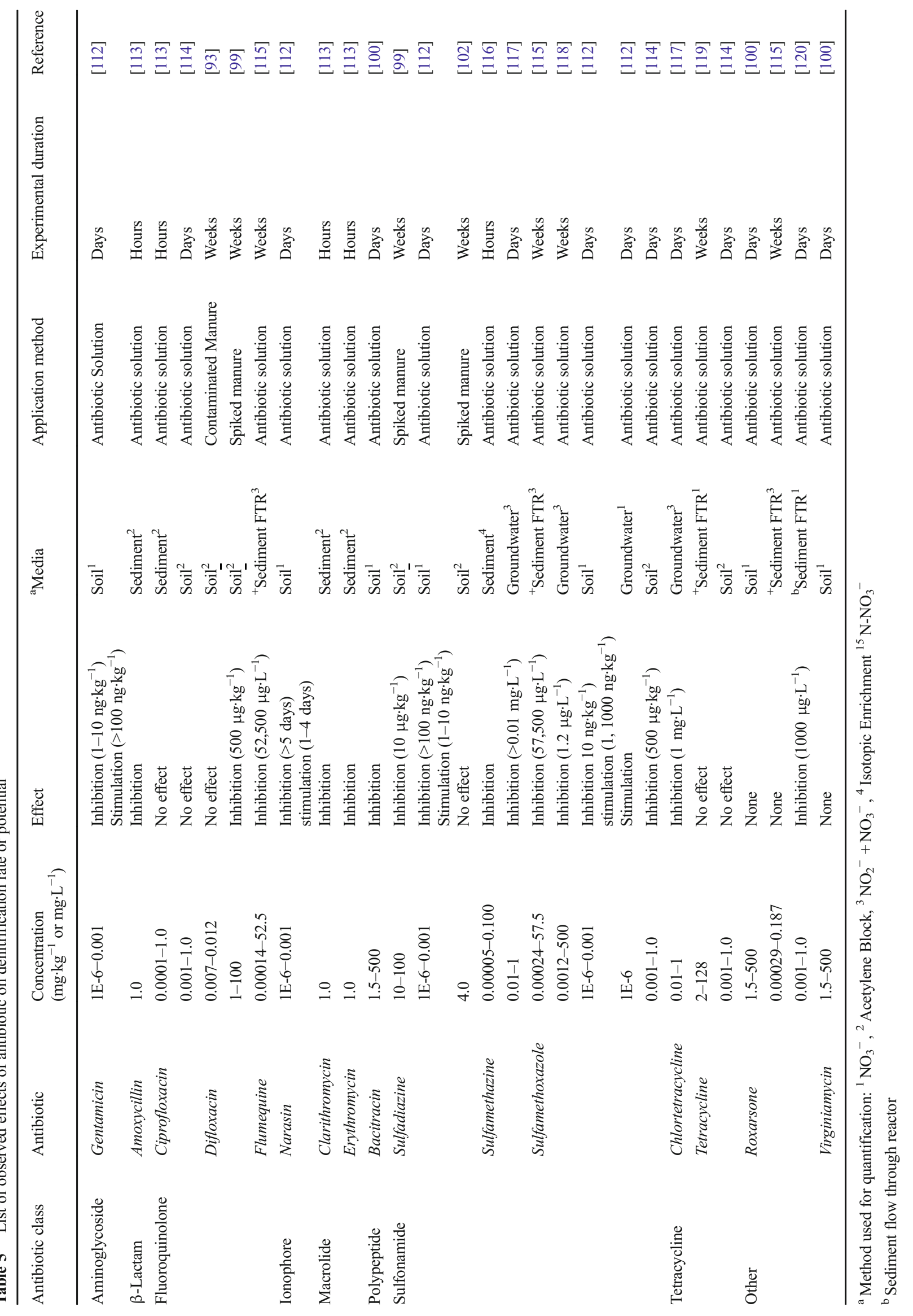


have investigated the effects of antibiotics on NO flux from soil or sediment.

\section{Overview of Current Measurement Methodology}

The results of these investigations allow few broad conclusions regarding the effects of antibiotics and antimicrobials on nitrification and denitrification. Total consensus is not expected because individual antibiotics target different types of organisms and vary in their efficacy. Inconsistent results among antibiotics of the same class or for a single antibiotic compound, however, likely are influenced by methodological differences. Konopka et al.'s [96] two investigations illustrate this point well. In their short-term study, $100 \mathrm{mg} \cdot \mathrm{kg}^{-1}$ of BAC/ MON/ROX stimulated nitrification in soil mesocosms but lower doses $\left(0.1-10 \mathrm{mg} \cdot \mathrm{kg}^{-1}\right)$ had the same effect in field soils, but it was not observed until 1 year after the initial application. Had the field study been terminated after a few weeks, the authors would have reported that the lower doses have no effect, which highlights the need for a higher degree of consistency in terms of antibiotic dose and experimental duration. The results of individual experiments may also be influenced by natural variations in soil or sediment composition or the use of nutrient amendments. For example, Konopka et al. [96] reported increased nitrification and a positive shift in the AOA:AOB ratio in a loamy soil 7 days after it was dosed with $100 \mathrm{mg} \cdot \mathrm{kg}^{-1}$ BAC. In contrast, Banerjee et al. [100] reported no effect within 5 days after applying a comparable dose to a silty loam. An accompanying fatty acid methyl ester (FAME) profile analysis indicated that there was no significant change in the microbial community [100]. Notable differences between the two studies include the soil properties and the use of $\mathrm{N}$ fertilizer amendments. The organic carbon (OC) content of the soil used by Banerjee et al. was higher (3.9 vs. $2.5 \%$ ), and the soil was amended with $\left(\mathrm{NH}_{4}\right)_{2} \mathrm{SO}_{4}$ to help promote nitrification. Higher OC may enhance the role of heterotrophic nitrifiers, and if these organisms are less sensitive to BAC than autotrophic AOB, there may be less opportunity for AOA to take a more prominent role in nitrification. Alternately, amending the soil with $\left(\mathrm{NH}_{4}\right)_{2} \mathrm{SO}_{4}$ stimulates all nitrifying activity, and the resulting growth may compensate for any negative impacts that BAC may have on one or more individual groups of organisms.

Antibiotics that affect the structure and function of the soil or sediment microbial community may also alter nitrification pathways or denitrification product ratios. Where this occurs, standard methods for quantifying nitrification may not accurately measure the nitrification rate in soils exposed to antibiotics or capture shifts in the $\mathrm{N}_{2} \mathrm{O}: \mathrm{N}_{2}$ ratio. Nitrification is most commonly measured by monitoring the size of the reactant $\left(\mathrm{NH}_{4}{ }^{+}\right)$or product $\left(\mathrm{NO}_{2}{ }^{-} \mathrm{NO}_{3}{ }^{-}\right)$pools over time. Under nitrifying conditions, the $\mathrm{NH}_{4}{ }^{+}$pool will be reduced over time, and nitrification rate is taken as $\Delta \mathrm{NH}_{4}^{+} / \Delta \mathrm{t}$. $\mathrm{NH}_{4}^{+}$can be extracted from soil and sediment with a concentrated salt solution $(2 \mathrm{M} \mathrm{KCl})$ and quantified colorimetrically. The indophenol blue method [123] is most common and can be performed manually or by automated flow injection analysis. Since autotrophic oxidation to $\mathrm{NO}_{3}^{-}$via $\mathrm{NO}_{2}^{-}$is the dominant nitrification pathway in soil and sediment [124], nitrification rates determined by the product pools are measured by quantifying the accumulation of $\mathrm{NO}_{2}{ }^{-}+\mathrm{NO}_{3}{ }^{-}$over time. Both are easily extracted from soil and sediment into aqueous solution and can subsequently be quantified by a number of reliable and inexpensive colorimetric methods, e.g., cadmium reduction $[125,126]$. Under some conditions, $\mathrm{NO}_{3}{ }^{-}$may undergo rapid reduction to $\mathrm{N}_{2} \mathrm{O}$ or $\mathrm{N}_{2}$ (denitrification) and preclude reliable measurements of nitrification from the combined $\mathrm{NO}_{2}{ }^{-}+\mathrm{NO}_{3}{ }^{-}$pool. In these circumstances, an inhibitor such as sodium chlorate can be added to the soil to prevent the oxidation of $\mathrm{NO}_{2}^{-}$to $\mathrm{NO}_{3}^{-}$. When inhibitors are used, the measurement is called potential nitrification and is determined from the increase of $\mathrm{NO}_{2}^{-}$over time [127].

Alternate nitrification pathways that affect the concentration of $\mathrm{NO}_{2}{ }^{-}$and $\mathrm{NO}_{3}{ }^{-}$are not captured by these methods. For example, nitrifier nitrification $(\mathrm{NN})$, nitrifier denitrification (ND), and annamox each influence the size of the $\mathrm{NO}_{2}{ }^{-}$pool. $\mathrm{NN}$ lowers $\mathrm{NO}_{2}^{-}$production rate by oxidizing $\mathrm{NH}_{2} \mathrm{OH}$ to $\mathrm{N}_{2} \mathrm{O}$ and the latter (ND and annamox) consume $\mathrm{NO}_{2}{ }^{-}$. Assuming no change to total nitrification, an increase in the ratio of any of these pathways to complete oxidation $\left(\mathrm{NH}_{4}{ }^{+} \rightarrow \mathrm{NO}_{3}{ }^{-}\right)$will cause the nitrification rates to be underestimated when the $\mathrm{NO}_{2}{ }^{-}+\mathrm{NO}_{3}{ }^{-}$pool is used for quantification. If the shift is significant, the apparent reduction in nitrification rate may even be reported as inhibition. Similarly, if antibiotics reduced the contributions of NN, ND, and annamox to total nitrification, the $\mathrm{NO}_{2}{ }^{-}+\mathrm{NO}_{3}{ }^{-}$pool would increase in size and cause the nitrification rate to be overestimated and reported as stimulation. In order to avoid over/underestimation of nitrification rate, we recommend that determination of $\mathrm{NO}$ and $\mathrm{N}_{2} \mathrm{O}$ flux be included in future studies evaluating the effects of antibiotics on nitrification rate.

The most common methods for quantifying the effects of antibiotics on denitrification rate include monitoring the depletion of $\mathrm{NO}_{3}{ }^{-}$over time under anaerobic conditions and the acetylene block method. In the latter method, acetylene gas is added to gas-tight sample vials to inhibit reduction of $\mathrm{N}_{2} \mathrm{O}$ to $\mathrm{N}_{2}$, and denitrification rate is determined from the concentration of $\mathrm{N}_{2} \mathrm{O}$ in headspace [128]. $\mathrm{NO}_{3}{ }^{-}$measurements often require destructive sampling, so the acetylene block method is better suited to evaluate changes on shorter time scales, i.e., hours vs. days. Since denitrification follows a linear pathway, neither method is prone to over/underestimating denitrification as a result of changes to the microbial community but they also do not provide a coincident measure of the $\mathrm{N}_{2} \mathrm{O}: \mathrm{N}_{2}$ or NO: $\mathrm{N}_{2}$ flux ratios. Where $\mathrm{NO}_{3}{ }^{-}$is used as a metric, $\mathrm{N}_{2} \mathrm{O}$ flux 
is not considered at all. In the latter, $\mathrm{NO}$ is not quantified, and acetylene inhibits the reduction of $\mathrm{N}_{2} \mathrm{O}$ to $\mathrm{N}_{2}$ which will mask shifts in the $\mathrm{N}_{2}: \mathrm{N}_{2} \mathrm{O}$ ratio that may result from antibiotic exposure. Furthermore, both of these methods are conducted under fully anaerobic conditions to prevent nitrification from adding to the $\mathrm{NO}_{3}{ }^{-}$pool during the measurement period. This may be realistic for sediment, but denitrification in soils is more often limited to anaerobic hotspots that develop in micropore spaces and rarely occurs in complete isolation from nitrification. It may therefore be more relevant in soils to use stable ${ }^{15} \mathrm{~N}$ methods to quantify nitrification and denitrification rates.

Stable ${ }^{15} \mathrm{~N}$ isotopic tracers have the advantage that they can capture process-rate changes in nitrification and denitrification under conditions favoring coupled nitrification-denitrification. For example, the isotope dilution method uses a ${ }^{15} \mathrm{~N}$ $\mathrm{KNO}_{3}$ enrichment, and nitrification rate $\left(\mu \mathrm{g} \mathrm{N} \mathrm{g}^{-1}\right.$ soil d $\left.{ }^{-1}\right)$ may be calculated from ${ }^{15} \mathrm{~N}_{-} \mathrm{NO}_{3}{ }^{-}$dilutions according to the equations 1-11 of Kirkham and Bartholomew [129]. Denitrification rate $\left(\mu \mathrm{g} \mathrm{N} \mathrm{g}^{-1}\right.$ soil d $\left.{ }^{-1}\right)$ can also be determined from this enrichment using the ratios of ${ }^{28} \mathrm{~N}^{2},{ }^{29} \mathrm{~N}_{2}$, and ${ }^{30} \mathrm{~N}_{2}$ in headspace [130]. These methods can be paired with a ${ }^{15} \mathrm{~N}$ $\mathrm{NH}_{4}{ }^{+}$enrichment to concurrently measure organic $\mathrm{N}$ mineralization rates, which have not previously been measured in soils treated with antibiotics. Because they allow for quantification of the cumulative effects of the antibiotic on reaction rate and the resultant accumulation of $\mathrm{N}_{2} \mathrm{O}$ and $\mathrm{NO}_{3}{ }^{-}$, combining these measurements may be particularly relevant under fluctuating soil moisture conditions or when changes to the soil/sediment microbial community are probable.

\section{Conclusions and Prospects}

Current data indicate that the biogeochemical $\mathrm{N}$ cycle may be altered by environmentally relevant concentrations of antibiotics. Of the processes evaluated, nitrification appears less sensitive to antibiotics than denitrification at therapeutic doses $\left(<\mathrm{mg} \cdot \mathrm{kg}^{-1}\right)$. Although $\mathrm{mg} \cdot \mathrm{kg}^{-1}$ concentrations have been reported in wastewater and wastewater sludge where inhibition of either process may reduce overall wastewater treatment efficiency, there remains inadequate information regarding the effects at sub-therapeutic concentrations to conclusively evaluate the risk to ecosystem function in aquatic and terrestrial environments. As limits of detection have improved, it has become evident that a number of antibiotics are present in soils at concentrations in the low ng. $\mathrm{kg}^{-1}$ range, and thus, there is a clear need to examine a broader range of concentrations when testing for effects on $\mathrm{N}$ processing. Where environmentally relevant concentrations have been evaluated, the sulfonamide group appears to have the greatest potential to significantly affect microbial $\mathrm{N}$ cycling. Although this partially is due to the fact that the sulfonamides have been the most frequently tested antibiotics, the associated risk is enhanced by their high mobility in soil and sediment and the apparent sensitivity of both nitrifiers and denitrifiers to concentrations as low as 1 or $1 \mathrm{ng} \cdot \mathrm{L}^{-1}$.

The number of studies exploring the impacts of antibiotics on biogeochemical $\mathrm{N}$ cycling has notably increased in recent years; yet, there are a number of substantial weaknesses highlighted by this review. Like Roose-Amsalag and Laverman [23], we find that there is a distinct lack of consistency among different studies in terms of antibiotic dose, substrate, method by which nitrification and/or denitrification are measured, and the duration of the experiment. The result is that comparisons between individual studies are difficult, if not impossible. Second, all of the research summarized here focuses on process rates and with little or no regard to the measurable outcome of process-related change such as the accumulation of eco-toxic $\mathrm{NO}_{3}{ }^{-}$, $\mathrm{NO}$, and $\mathrm{N}_{2} \mathrm{O}$. Furthermore, common methodological approaches to quantify process rates may over/underestimate the effects of antibiotics on a given process where the size of the N-pool used for quantification is affected by changes to the redox pathway.

Addressing these concerns will require a more systematic and comprehensive approach to future investigations. Recommendations include establishing a standardized set of antibiotic doses that include sub-therapeutic concentrations $\left(<\mu \mathrm{g} \mathrm{kg}^{-1}\right)$ and including testing antibiotics from the $\beta$ lactams group. Where the effects of antibiotics on process rate are evaluated, e.g., nitrification or denitrification, more comprehensive measurement tools should be considered to avoid either (1) over/underestimating the effects of antibiotic exposure or (2) masking the accumulation of eco-toxic compounds. For example, nitrification measurements can be modified to include $\mathrm{NO}$ and $\mathrm{N}_{2} \mathrm{O}$ flux measurements. In addition to providing relevant information about the effects of the antibiotic on these fluxes, including these measurements may also afford a more accurate determination of the effects of antibiotics on nitrification. Where possible, isotopic tracer studies can be substituted for the acetylene block methods to allow simultaneous measurements of denitrification and $\mathrm{N}_{2} \mathrm{O}$ flux. Furthermore, a combination of isotope dilution techniques can be combined to study the effects of antibiotics on coupled nitrification-denitrification in soils, which would allow net effect of antibiotics on the resulting accumulation of $\mathrm{N}_{2} \mathrm{O}$ and leachable $\mathrm{NO}_{3}{ }^{-}$in soils to be effectively determined. Although isotopic tracer studies are more expensive and timeconsuming than the other methods discussed (e.g., mineral $\mathrm{N}$ diffusions for ${ }^{15} \mathrm{~N}$ analysis require a $1-3$-week incubation [131]), these may be well-suited for long-term investigations. There is evidence that the effects of antibiotic exposure may not be evident for as long as 1 year after initial exposure, highlighting the need for future studies to include multi-year investigations in which antibiotics applications are replicated over time or delivered continuously. 
Acknowledgments This work is partially supported by a PSC-CUNY grant (\#68546-0046).

\section{Compliance with Ethical Standards}

Conflict of Interest The authors have no conflicts of interest to declare.

\section{References}

1. Wise R. Antimicrobial resistance: priorities for action. J Antimicrob Chemother. 2002;49(4):585-6.

2. Teuber M. Veterinary use and antibiotic resistance. Curr Opin Microbiol. 2001;4:493-9.

3. Boxall ABA et al. Peer reviewed: are veterinary medicines causing environmental risks? Environ Sci Technol. 2003;37(15): 286A-94A

4. Sarmah AK, Meyer MT, Boxall ABA. A global perspective on the use, sales, exposure pathways, occurrence, fate and effects of veterinary antibiotics (VAs) in the environment. Chemosphere. 2006;65(5):725-9.

5. Kemper N. Veterinary antibiotics in the aquatic and terrestrial environment. Ecol Indic. 2008;8(1):1-13.

6. Hirsch $\mathrm{R}$ et al. Occurrence of antibiotics in the aquatic environment. Sci Total Environ. 1999;225(1-2):109-18.

7. Watkinson AJ, Murby EJ, Costanzo SD. Removal of antibiotics in conventional and advanced wastewater treatment: implications for environmental discharge and wastewater recycling. Water Res. 2007;41(18):4164-76.

8. Andersson DI, Hughes D. Microbiological effects of sublethal levels of antibiotics. Nat Rev Micro. 2014;12(7):465-78.

9. Ding C, He J. Effect of antibiotics in the environment on microbial populations. Appl Microbiol Biotechnol. 2010;87(3):925-41.

10. Galloway JN, Cowling EB. Reactive nitrogen and the world: 200 years of change. AMBIO. 2002;31(2):64-71.

11. Carpenter SR et al. Nonpoint pollution of surface waters with phosphorus and nitrogen. Ecol Appl. 1998;8(3):559-68.

12. Rabalais NN, Turner RE, Wiseman WJ. Gulf of Mexico Hypoxia, a.k.a. "The Dead Zone". Annu Rev Ecol Evol Syst. 2002;33(1): 235-63.

13. Galloway JN et al. The nitrogen cascade. Biosci. 2003;53(4):34156.

14. Camargo JA, Alonso A, Salamanca A. Nitrate toxicity to aquatic animals: a review with new data for freshwater invertebrates. Chemosphere. 2005;58(9):1255-67.

15. Ward $\mathrm{MH}$ et al. Workgroup report: drinking-water nitrate and health - recent findings and research needs. Environ Health Perspect. 2005;113(11):1607-14.

16. Howarth RW et al. Nitrogen use in the United States from 19612000 and potential future trends. AMBIO. 2002;31(2):88-96.

17. van Breemen $\mathrm{N}$ et al. Where did all the nitrogen go? Fate of nitrogen inputs to large watersheds in the northeastern U.S.A. Biogeochem. 2002;57-58(1):267-93.

18. Schlesinger WH. On the fate of anthropogenic nitrogen. Proc Natl Acad Sci U S A. 2009;106(1):203-8

19. Snyder CS et al. Review of greenhouse gas emissions from crop production systems and fertilizer management effects. Agric Ecosys Environ. 2009;133(3-4):247-66.

20. Ravishankara AR, Daniel JS, Portmann RW. Nitrous oxide (N2O): the dominant ozone-depleting substance emitted in the 21st century. Science. 2009;326(5949):123-5.
21. Ricciardolo FL et al. Nitric oxide in health and disease of the respiratory system. Physiol Rev. 2004;84(3):731-65.

22. Skiba U, Smith KA, Fowler D. Nitrification and denitrification as sources of nitric oxide and nitrous oxide in a sandy loam soil. Soil Biol Biochem. 1993;25(11):1527-36.

23. Roose-Amsaleg C, Laverman AM. Do antibiotics have environmental side-effects? Impact of synthetic antibiotics on biogeochemical processes. Environ Sci Pollut Res, 2015: p. 1-13.

24. Kümmerer K. Antibiotics in the aquatic environment - a reviewpart I. Chemosphere. 2009;75(4):417-34.

25. Kümmerer $\mathrm{K}$ et al. Standardized tests fail to assess the effects of antibiotics on environmental bacteria. Water Res. 2004;38(8): 2111-6.

26. Leal RMP et al. Occurrence and sorption of fluoroquinolones in poultry litters and soils from São Paulo State, Brazil. Sci Total Environ. 2012;432:344-9.

27. Zhou L-J et al. Excretion masses and environmental occurrence of antibiotics in typical swine and dairy cattle farms in China. Sci Total Environ. 2013;444:183-95

28. Hou J et al. Occurrence and distribution of sulfonamides, tetracyclines, quinolones, macrolides, and nitrofurans in livestock manure and amended soils of Northern China. Environ Sci Pollut Res. 2015;22:4545-54.

29. Ho YB et al. Occurrence of veterinary antibiotics and progesterone in broiler manure and agricultural soil in Malaysia. Sci Total Environ. 2014;488-489:261-7.

30. Michael I et al. Urban wastewater treatment plants as hotspots for the release of antibiotics in the environment: a review. Water Res. 2013;47(3):957-95.

31. Verlicchi P et al. Hospital effluent: investigation of the concentrations and distribution of pharmaceuticals and environmental risk assessment. Sci Total Environ. 2012;430:109-18.

32. USDA. Manure use for fertilizer and for energy. Washington: Report for Congress; 2009.

33. USDA. Marketing US organic foods: recent trends from farmers to consumers. Washington: Economic Information Bulletin; 2009.

34. Xing GX, Zhu ZL. Regional nitrogen budgets for China and its major watersheds. Biogeochem. 2002;57-58(1):405-27.

35. Pan M, Wong CKC, Chu LM. Distribution of antibiotics in wastewater-irrigated soils and their accumulation in vegetable crops in the Pearl River delta, Southern China. J Agr Food Chem. 2014;62(46):11062-9.

36. Vazquez-Roig P et al. Determination of pharmaceuticals in soils and sediments by pressurized liquid extraction and liquid chromatography tandem mass spectrometry. J Chromatogr A. 2010;1217(16):2471-83.

37. Huang $X$ et al. Occurrence and distribution of veterinary antibiotics and tetracycline resistance genes in farmland soils around swine feedlots in Fujian Province. China Environ Sci Pollut Res. 2013;20:9066-74.

38. Wu X-L et al. Distribution and risk assessment of quinolone antibiotics in the soils from organic vegetable farms of a subtropical city, Southern China. Sci Total Environ. 2014;487:399-406.

39. Gao L et al. Occurrence and distribution of antibiotics in urban soil in Beijing and Shanghai, China. Environ Sci Pollut Res. 2015;22(15):11360-71.

40. Rutgersson $\mathrm{C}$ et al. Fluoroquinolones and qnr genes in sediment, water, soil, and human fecal flora in an environment polluted by manufacturing discharges. Environ Sci Technol. 2014;48(14): 7825-32.

41. Li Y-W et al. Investigation of sulfonamide, tetracycline, and quinolone antibiotics in vegetable farmland soil in the Pearl River delta area, Southern China. J Agr Food Chem. 2011;59(13):7268-76.

42. Shi $Y$ et al. Investigation of fluoroquinolones, sulfonamides and macrolides in long-term wastewater irrigation soil in Tianjin, China. Bull Environ Contam Toxicol. 2012;89(4):857-61. 
43. Karc1 A, Balcığlu IA. Investigation of the tetracycline, sulfonamide, and fluoroquinolone antimicrobial compounds in animal manure and agricultural soils in Turkey. Sci Total Environ. 2009;407(16):4652-64.

44. Bak SA et al. Quantification of four ionophores in soil, sediment and manure using pressurised liquid extraction. J Chromatogr A. 2013;1307:27-33.

45. Chen $\mathrm{C}$ et al. Occurrence of antibiotics and antibiotic resistances in soils from wastewater irrigation areas in Beijing and Tianjin, China. Environ Poll. 2014;193:94-101.

46. Watanabe $\mathrm{N}$ et al. Use and environmental occurrence of antibiotics in freestall dairy farms with manured forage fields. Environ Sci Technol. 2010;44(17):6591-600.

47. Awad YM et al. Veterinary antibiotics contamination in water, sediment, and soil near a swine manure composting facility. Environ Earth Sci. 2014;71:1443-0.

48. Tso J et al. Simultaneous analysis of free and conjugated estrogens, sulfonamides, and tetracyclines in runoff water and soils using solid-phase extraction and liquid chromatography-tandem mass spectrometry. J Agr Food Chem. 2011;59(6):2213-22.

49. Wu L et al. Occurrence and distribution of heavy metals and tetracyclines in agricultural soils after typical land use change in east China. Environ Sci Pollut Res. 2013;20(12):8342-54.

50. Shi $\mathrm{H}$ et al. Occurrence and distribution of antibiotics in the surface sediments of the Yangtze Estuary and nearby coastal areas. Mar Pollut Bull. 2014;83(1):317-23.

51. Li W et al. Occurrence of antibiotics in water, sediments, aquatic plants, and animals from Baiyangdian Lake in North China. Chemosphere. 2012;89(11):1307-15.

52. Arikan OA, Rice C, Codling E. Occurrence of antibiotics and hormones in a major agricultural watershed. Desalination. 2008;226(1-3):121-33.

53. Zhou L-J et al. Trends in the occurrence of human and veterinary antibiotics in the sediments of the Yellow River, Hai River and Liao River in northern China. Environ Poll. 2011;159(7):1877-85.

54. Yang J-F et al. Simultaneous determination of four classes of antibiotics in sediments of the Pearl Rivers using RRLC-MS/MS. Sci Total Environ. 2010;408(16):3424-32.

55. Cheng $\mathrm{D}$, et al. Occurrence and partitioning of antibiotics in the water column and bottom sediments from the Intertidal Zone in the Bohai Bay, China. Wetlands, 2014: p. 1-13.

56. Angulo FJ, World Health Organization, et al. Ranking of antimicrobials according to their importance in human medicine: a critical step for developing risk management strategies for the use of antimicrobials in food production animals. Clin Infect Dis. 2009;49(1):132-41.

57. Barbosa $\mathrm{J}$ et al. Comparison between capillary electrophoresis, liquid chromatography, potentiometric and spectrophotometric techniques for evaluation of $\mathrm{pKa}$ values of zwitterionic drugs in acetonitrile-water mixtures. Anal Chim Acta. 2001;437(2):309-21.

58. Tolls J. Sorption of veterinary pharmaceuticals in soils: a review. Environ Sci Technol. 2001;35(17):3397-406.

59. Walters E, McClellan K, Halden RU. Occurrence and loss over three years of 72 pharmaceuticals and personal care products from biosolids-soil mixtures in outdoor mesocosms. Water Res. 2010;44(20):6011-20.

60. Takács-Novák K et al. Lipophilicity of antibacterial fluoroquinolones. Int J Pharm. 1992;79(1-3):89-96.

61. Drakopoulos AI, Ioannou PC. Spectrofluorimetric study of the acid-base equilibria and complexation behavior of the fluoroquinolone antibiotics ofloxacin, norfloxacin, ciprofloxacin and pefloxacin in aqueous solution. Anal Chim Acta. 1997;354(1):197-204.
62. McFarland JW et al. Quantitative structure-activity relationships among macrolide antibacterial agents: in vitro and in vivo potency against Pasteurella multocida. J Med Chem. 1997;40(9):1340-6.

63. Muñoz I et al. Chemical evaluation of contaminants in wastewater effluents and the environmental risk of reusing effluents in agriculture. TrAC Trends. 2009;28(6):676-94.

64. Beausse J. Selected drugs in solid matrices: a review of environmental determination, occurrence and properties of principal substances. TrAC Trends. 2004;23(10-11):753-61.

65. Huber MM et al. Oxidation of pharmaceuticals during ozonation and advanced oxidation processes. Environ Sci Technol. 2003;37(5):1016-24.

66. Schlüsener MP, Bester K. Persistence of antibiotics such as macrolides, tiamulin and salinomycin in soil. Environ Poll. 2006;143(3):565-71.

67. Qiang Z, Adams C. Potentiometric determination of acid dissociation constants $(\mathrm{pK}$ a) for human and veterinary antibiotics. Water Res. 2004;38(12):2874-90.

68. ter Laak TL, Gebbink WA. Estimation of soil sorption coefficients of veterinary pharmaceuticals from soil properties. Environ Toxicol Chem. 2006;25(4):933-41.

69. Ma Y et al. Occurrences and regional distributions of 20 antibiotics in water bodies during groundwater recharge. Sci Total Environ. 2015;518:498-506.

70. Boxall $\mathrm{AB}$ et al. The sorption and transport of a sulphonamide antibiotic in soil systems. Toxicol Lett. 2002;131(1):19-28.

71. Accinelli $\mathrm{C}$ et al. Environmental fate of two sulfonamide antimicrobial agents in soil. J Agr Food Chem. 2007;55(7):2677-82.

72. Morishita $\mathrm{T}$ et al. Studies on absorption of drugs. VIII. Physiochemical factors affecting the absorption of sulfonamides from the rat small intestines. Chem Pharm Bull. 1973;21(10): 2309-22.

73. Thiele-Bruhn S. Pharmaceutical antibiotic compounds in soils-a review. J Plant Nutr Soil Sc. 2003;166(2):145-67.

74. Yang J-F et al. Biological degradation and microbial function effect of norfloxacin in a soil under different conditions. J Environ Sci Heal B. 2012;47(4):288-95.

75. McEwen SA, Fedorka-Cray PJ. Antimicrobial use and resistance in animals. Clin Infect Dis. 2002;34(Supplement 3):S93-S106.

76. Kolpin DW et al. Pharmaceuticals, hormones, and other organic wastewater contaminants in U.S. Streams, 1999-2000: a national reconnaissance. Environ Sci Technol. 2002;36(6):1202-11.

77. Lin K, Gan J. Sorption and degradation of wastewater-associated non-steroidal anti-inflammatory drugs and antibiotics in soils. Chemosphere. 2011;83(3):240-6

78. Lin C-E, Chang C-C, Lin W-C. Migration behavior and separation of sulfonamides in capillary zone electrophoresis III. Citrate buffer as a background electrolyte. J Chromatogr A. 1997;768(1):105-12.

79. Aarestrup F, Jenser L. Use of antimicrobials in food animal production, in Foodborne Diseases, Simjee S, Editor 2007, Humana Press. p. 405-417.

80. Stephens $\mathrm{C}$ et al. Acidity constants of the tetracycline antibiotics. J Am Chem Soc. 1956;78(16):4155-8.

81. Halling-Sørensen B et al. Dissipation and effects of chlortetracycline and tylosin in two agricultural soils: a field-scale study in southern Denmark. Environ Toxicol Chem. 2005;24(4):802-10.

82. Li L-L et al. Sorption and dissipation of tetracyclines in soils and compost. Pedosphere. 2010;20(6):807-16.

83. Kulshrestha P, Giese RF, Aga DS. Investigating the molecular interactions of oxytetracycline in clay and organic matter: insights on factors affecting its mobility in soil. Environ Sci Technol. 2004;38(15):4097-105.

84. Aga DS et al. Determination of the persistence of tetracycline antibiotics and their degradates in manure-amended soil using enzyme-linked immunosorbent assay and liquid 
chromatography-mass spectrometry. J Agr Food Chem. 2005;53(18):7165-71.

85. Arp DJ, Sayavedra-Soto LA, Hommes NG. Molecular biology and biochemistry of ammonia oxidation by Nitrosomonas Europaea. Arch Microbiol. 2002;178(4):250-5.

86. Ferguson SJ, Richardson DJ, van Spanning RJ. Chapter 14 Biochemistry and molecular biology of nitrification, in Biology of the nitrogen cycle, Bothe H, Ferguson SJ, Newton WE, Editors. 2007. p. 209-222.

87. Watson SW, Valois FW, Waterbury JB. The family nitrobacteraceae. In: Starr M et al., editors. The prokaryotes. Berlin Heidelberg: Springer; 1981. p. 1005-22.

88. Papen $\mathrm{H}$ et al. Heterotrophic nitrification by Alcaligenes faecalis: $\mathrm{NO}_{2}^{-}, \mathrm{NO}_{3}^{-}, \mathrm{N}_{2} \mathrm{O}$, and $\mathrm{NO}$ production in exponentially growing cultures. Appl Environ Microbiol. 1989;55(8):2068-72.

89. Thomson AJ et al. Biological sources and sinks of nitrous oxide and strategies to mitigate emissions. Philos T Roy Soc B. 2012;367:1157-68

90. Zhu X et al. Ammonia oxidation pathways and nitrifier denitrification are significant sources of $\mathrm{N}_{2} \mathrm{O}$ and $\mathrm{NO}$ under low oxygen availability. Proc Natl Acad Sci U S A. 2013;110(16):6328-33.

91. Luis Campos $\mathbf{J}$ et al. Effect of two broad-spectrum antibiotics on activity and stability of continuous nitrifying system. Appl Biochem Biotechnol. 2001;95(1):1-10.

92. Cui $\mathrm{H}$ et al. Influence of ciprofloxacin on microbial community structure and function in soils. Biol Fertil Soils. 2014;50(6):939-47.

93. Rosendahl I et al. Persistence of the fluoroquinolone antibiotic difloxacin in soil and lacking effects on nitrogen turnover. J Environ Qual. 2012;41(4):1275-83.

94. Dokianakis SN, Kornaros ME, Lyberatos G. On the effect of pharmaceuticals on bacterial nitrite oxidation. Water Sci Technol. 2004;50(5):341-6.

95. Toth JD, Feng Y, Dou Z. Veterinary antibiotics at environmentally relevant concentrations inhibit soil iron reduction and nitrification. Soil Biol Biochem. 2011;43(12):2470-2.

96. Konopka M et al. Multi-year and short-term responses of soil ammonia-oxidizing prokaryotes to zinc bacitracin, monensin, and ivermectin, singly or in combination. Environ Toxicol Chem. 2015;34(3):618-25.

97. Louvet JN et al. Adverse effects of erythromycin on the structure and chemistry of activated sludge. Environ Poll. 2010;158(3): 688-93.

98. Alighardashi A et al. Acute sensitivity of activated sludge bacteria to erythromycin. J Hazard Mater. 2009;172(2):685-92.

99. Kotzerke A et al. Alterations in soil microbial activity and Ntransformation processes due to sulfadiazine loads in pig-manure. Environ Poll. 2008;153(2):315-22.

100. Banerjee S, D'Angelo E. Livestock antibiotic effects on nitrification, denitrification, and microbial community composition in soils. Open J Soil Sci. 2013;3(5):203-12.

101. Bressan CR et al. Toxicity of the colistin sulfate antibiotic used in animal farming to mixed cultures of nitrifying organisms. Water Air Soil Pollut. 2013;224(3):1-9.

102. Radl V et al. Drying and rewetting events change the response pattern of nitrifiers but not of denitrifiers to the application of manure containing antibiotic in soil. Appl Soil Ecol. 2015;95: 99-106.

103. Katipoglu-Yazan $\mathrm{T}$ et al. Acute impact of erythromycin and tetracycline on the kinetics of nitrification and organic carbon removal in mixed microbial culture. Bioresource Technol. 2013;144:410-9.

104. Di HJ et al. Nitrification driven by bacteria and not archaea in nitrogen-rich grassland soils. Nat Geosci. 2009;2(9):621-4.

105. Leininger $\mathrm{S}$ et al. Archaea predominate among ammoniaoxidizing prokaryotes in soils. Nature. 2006;442(7104):806-9.
106. Schauss K et al. Dynamics and functional relevance of ammoniaoxidizing archaea in two agricultural soils. Environ Microbiol. 2009;11(2):446-56.

107. Thiele-Bruhn S, Beck I-C. Effects of sulfonamide and tetracycline antibiotics on soil microbial activity and microbial biomass. Chemosphere. 2005;59(4):457-65.

108. Calabrese EJ, Baldwin LA. Defining hormesis. Hum Exp Toxicol. 2002;21:91-7.

109. Zumft WG. Cell biology and molecular basis of denitrification. Microbiol Mol Biol Rev. 1997;61(4):533-616.

110. van Spanning RJM, Richardson DJ, Ferguson SJ. Chapter 1introduction to the biochemistry and molecular biology of denitrification. In: Newton H, Bothe SJ, Ferguson WE, editors. Biology of the nitrogen cycle. Amsterdam: Elsevier; 2007. p. 3-11.

111. Hochstein LI, Tomlinson GA. The enzymes associated with denitrification. Annu Rev Microbiol. 1988;42(1):231-61.

112. DeVries SL et al. The effect of ultralow-dose antibiotics exposure on soil nitrate and $\mathrm{N}_{2} \mathrm{O}$ flux. Sci Reports. 2015;5:16818.

113. Costanzo SD, Murby J, Bates J. Ecosystem response to antibiotics entering the aquatic environment. Mar Pollut Bull. 2005;51(1-4): 218-23.

114. Conkle JL, White JR. An initial screening of antibiotic effects on microbial respiration in wetland soils. J Environ Sci Heal A. 2012;47(10):1381-90.

115. Yan $\mathrm{C}$ et al. The effect of environmental and therapeutic concentrations of antibiotics on nitrate reduction rates in river sediment. Water Res. 2013;47(11):3654-62.

116. Hou L et al. Effects of sulfamethazine on denitrification and the associated $\mathrm{N}_{2} \mathrm{O}$ release in estuarine and coastal sediments. Environ Sci Technol. 2015;49(1):326-33.

117. Ahmad $\mathrm{M}$ et al. Inhibitory effect of veterinary antibiotics on denitrification in groundwater: a microcosm approach. Scientific World J. 2014;2014:7.

118. Underwood JC et al. Effects of the antimicrobial sulfamethoxazole on groundwater bacterial enrichment. Environ Sci Technol. 2011;45(7):3096-101.

119. Roose-Amsaleg $\mathrm{C}$ et al. Chronic exposure of river sediments to environmentally relevant levels of tetracycline affects bacterial communities but not denitrification rates. Ecotoxicology. 2013;22(10):1467-78.

120. Laverman A, et al. Exposure to vancomycin causes a shift in the microbial community structure without affecting nitrate reduction rates in river sediments. Environ Sci Pollut Res, 2015: p. 1-8.

121. Bazylinski DA, Soohoo CK, Hollocher TC. Growth of pseudomonas aeruginosa on nitrous oxide. Appl Environ Microbiol. 1986;51(6):1239-46.

122. Jones CM et al. Phylogenetic analysis of nitrite, nitric oxide, and nitrous oxide respiratory enzymes reveal a complex evolutionary history for denitrification. Mol Biol Evol. 2008;25(9):1955-66.

123. Boo H-K, Ma TS. A simple method for determining ammonia in water at the ppm level. Mikrochim Acta. 1976;66(5-6):515-23.

124. Prosser JI. Chapter 15-the ecology of nitrifying bacteria. In: Newton H, Bothe SJ, Ferguson WE, editors. Biology of the nitrogen cycle. Amsterdam: Elsevier; 2007. p. 223-43.

125. Stock W. An evaluation of some manual colorimetric methods for the determination of inorganic nitrogen in soil extracts. Commun Soil Sci Plan. 1983;14(10):925-36.

126. Willis RB, Gentry CE. Automated method for determining nitrate and nitrite in water and soil extracts. Commun Soil Sci Plan. 1987;18(6):625-36.

127. Belser L, Mays E. Specific inhibition of nitrite oxidation by chlorate and its use in assessing nitrification in soils and sediments. Appl Environ Microbiol. 1980;39(3):505-10. 
128. Ryden J, Lund L, Focht D. Direct measurement of denitrification loss from soils: I. Laboratory evaluation of acetylene inhibition of nitrous oxide reduction. Soil Sci Soc Am J. 1979;43(1):104-10.

129. Kirkham P, Bartholomew WV. Equations for following nutrient transformations in soil, utilizing tracer data. Soil Sci Soc Am Pro. 1954;18:33-4.
130. Hauck RD, Melsted SW, Yankwich PE. Use of N-Isotope distribution in nitrogen gas in the study of denitrification. Soil Sci. 1958;86(5):287.

131. Brooks PD et al. Diffusion method to prepare soil extracts for automated nitrogen-15 analysis. Soil Sci Soc Am J. 1989;53(6): $1707-11$. 